\title{
Relationship between Weather Parameters and Incidence of Gram Pod Borer, Helicoverpa armigera on Chickpea
}

\author{
Keshav Mehra, Veer Singh
}

10.18805/IJARe.A-5818

\begin{abstract}
Background: Chickpea, Cicer arietinum which is considered as a "King of pulses" get adversely affected by several biotic and abiotic stresses, out of which gram pod borer, Helicoverpa armigera (Hübner) is the major one. The damage caused by $H$. armigera starts from vegetative growth and continues till maturity of the crop. This pest is causes 25 to 70 per cent pod damage in chickpea but in favorable conditions pod damage goes upto 95 per cent.

Methods: Present study was carried out during, rabi, 2014-15 and 2015-16 at Research Farm, College of Agriculture, Bikaner (Rajasthan). Correlation coefficient was worked out with weather parameters such as temperature (maximum and minimum), relative humidity (maximum and minimum), rainfall and sunshine hours. Multiple linear forms of regression model were also used to assess the effect of the weather parameters on the incidence of pod borer.

Result: The studies revealed that peak larval population of gram pod borer was recorded in the second fortnight of February thereafter, population declined abruptly. The larval population of pod borer on chickpea occurred low at vegetative and flowering stages and high at pod formation as well as at grain developmental stages. The temperature (maximum and minimum) and sunshine hours had significant positive correlation with larval population during rabi, 2015-16. The maximum relative humidity showed significant negative correlation during rabi, 2015-16 whereas, minimum relative humidity showed significant negative correlation with larval population during both the seasons. The rainfall showed significant positive correlation during rabi, 2014-15.
\end{abstract}

Key words: Chickpea, Correlation, Gram pod borer, Population, Weather parameters.

\section{INTRODUCTION}

Chickpea, Cicer arietinum (L.) also known as gram or bengal gram belongs to the family leguminosae. It is one of the most important and remunerative pulse crop of Rabiseason, grown around the world. Although all the pulses occupy a unique position in Indian agriculture as well as in the world but chickpea is considered as "king of pulses". The productivity of chickpea is adversely affected by several biotic and abiotic stresses, out of which gram pod borer, Helicoverpa armigera (Hubner) is the major one. The damage caused by $\mathrm{H}$. armigera starts from vegetative growth and continues till maturity of the crop (Dhingra et al., 2003). It is a very serious pest and has assumed the status of national pest in India because of its high fecundity, migratory behavior, cosmopolitan distribution, high adaptation to various climatic conditions and development of resistance to a wide range of insecticides (Gowda, 1996). Although it attacks chickpea throughout the crop growth, the damage caused during flowering and pod formation stages results in substantial yield loss. A single larva alone can destroy 30-40 pods before the maturity (Reed and Pawar, 1982). In Rajasthan, $H$. armigera caused 19-20 per cent reduction in grain yield of gram (Ameta and Thakar, 1988). The studies were undertaken to find out the correlation coefficient along with regression equation between pest population and key weather parameters to know the most favourable conditions.
Department of Entomology, College of Agriculture, Swami Keshwanand Rajasthan Agricultural University, Bikaner-334 001, Rajasthan, India.

Corresponding Author: Keshav Mehra, Department of Entomology, College of Agriculture, Swami Keshwanand Rajasthan Agricultural University, Bikaner-334 001, Rajasthan, India.

Email: keshav.mehra35@gmail.com

How to cite this article: Mehra, K., Singh, V. (2021). Relationship between Weather Parameters and Incidence of Gram Pod Borer, Helicoverpa armigera on Chickpea. Indian Journal of Agricultural Research. DOI: 10.18805/IJARe.A-5818.

Submitted: 08-05-2021 Accepted: 19-11-2021 Online: 22-12-2021

\section{MATERIALS AND METHODS}

The experiment was conducted at Research Farm, College of Agriculture, Bikaner (Rajasthan) to study the relationship between weather parameters and incidence of $H$. armigera on chickpea, the variety GNG-1581 was sown on $15^{\text {th }}$ October during rabi, 2014-15 and on $17^{\text {th }}$ October during rabi, 2015-16 in a plot of $10 \times 10 \mathrm{~m}^{2}$. The row to row and plant to plant distance of 30 and $10 \mathrm{~cm}$ was maintained, respectively. Population of $H$. armigera was recorded at weekly intervals on chickpea. The observations on the incidence of $H$. armigera infesting chickpea were recorded by counting the larval population per meter row length from five randomly selected spots in the plot. 
Correlation coefficient was worked out with weather parameters such as temperature (maximum and minimum), relative humidity (maximum and minimum), rainfall and sunshine hours. Following formula was used for calculating correlation coefficient.

$$
r X_{1} Y_{1}=\frac{\sum X_{1} Y_{1}-\frac{\sum X_{1} \sum Y_{1}}{n}}{\sqrt{\left[\sum X_{1}^{2}-\frac{\left(\sum X_{1}\right)^{2}}{n}\right]\left[\sum Y_{1}^{2}-\frac{\left(\sum Y_{1}\right)^{2}}{n}\right]}}
$$

Where,

$r X_{1} Y_{1}=$ Simple correlation coefficient.

$\mathrm{X}_{1}=$ Independent variable i.e. abiotic component.

$Y_{1}=$ Dependent variable i.e. pest.

$\mathrm{n}=$ Number of observations.

Multiple linear forms of regression model was also used to assess the effect of the weather parameters on the incidence of pod borer.

$$
\mathrm{Y}=\mathrm{a}+\mathrm{b}_{1} \mathrm{X}_{1}+\mathrm{b}_{2} \mathrm{X}_{2}+\ldots \ldots \ldots \ldots \ldots+\mathrm{b}_{5} \mathrm{X}_{5}+\mathrm{Ui}
$$

Where,

$\mathrm{Y}=$ Larval population of $H$. armigera.

$\mathrm{a}=$ constant.

$\mathrm{x}_{1}=$ Maximum temperature $\left({ }^{\circ} \mathrm{C}\right)$.

$\mathrm{x}_{2}=$ Minimum temperature $\left({ }^{\circ} \mathrm{C}\right)$.

$x_{3}=$ Maximum relative humidity (\%).

$x_{4}=$ Minimum relative humidity $(\%)$.

$x_{5}=$ Rainfall $(\mathrm{mm})$.

$\mathrm{x}_{6}=$ Sunshine hours (hrs).

$\mathrm{Ui}=$ Error term.

\section{RESULTS AND DISCUSSION}

\section{Effect of weather parameters on the incidence of $\boldsymbol{H}$. armigera}

The data presented in Table 1 and Fig 1,2 revealed that the larval population of $H$. armigera first appeared in the third and fourth week of January during rabi, 2014-15 and 201516 , respectively. Initially only 0.3 and 0.9 larva per meter row length (mrl) were recorded during rabi, 2014-15 and 2015-16, respectively. The present results are in agreement with those of Lal (1996), Reddy et al. (2009) and Dhaka et al. (2011), who reported activity of larvae of $H$. armigera during the months of January and February. The larval population increased gradually after appearance with the vegetative growth of the chickpea and attained its peak in the fourth week of February (5.8 larvae per mrl) during rabi, 2014-15 and third week of February (6.0 larvae per mrl) during rabi, 2015-16; there after, population declined abruptly. The results corroborate the findings of Gupta and Chandel (2008), Dhaka et al. (2011), Pandey et al. (2012), Sharma et al. (2012) and Shinde et al. (2013) who reported peak period of larval infestation in last week of February and beginning of March.

Correlation between weather parameters and larval population of $\boldsymbol{H}$. armigera

The correlation studies (Table 2) revealed that during first year (rabi, 2014-15) the larval population showed non- significant positive correlation with maximum temperature and minimum temperature $(r=0.022$ and 0.163 , respectively). These results corroborates with findings of Krishna et al. (2007), Gupta and Chandel (2008), Reddy et al. (2009), Sharma et al. (2012) and Mahawar et al. (2015), who reported positive non-significant correlation with larval population and temperature. During second year (rabi, 2015-16), the significant positive correlation was also existed between larval population and maximum and minimum temperature ( $r=0.884$ and 0.898). Kulhari and Singh (2008), Pandey et al. (2012), Shinde et al. (2013) and Yadav et al. (2016) also computed significant positive correlation between larval population and temperature, which supports the present findings.

Maximum relative humidity showed negative nonsignificant $(r=-0.110)$ and significant correlation $(r=-0.761)$ with larva population during first and second year, respectively, while minimum relative humidity showed significant negative correlation during both the years $(r=-0.588$ and -0.582 , respectively). The present finding confirms with the results

Table 1: Incidence of $H$. armigera on chickpea during rabi, 201415 and 2015-16.

\begin{tabular}{lccc}
\hline & & \multicolumn{2}{c}{$\begin{array}{c}\text { Mean larval population per } \\
\text { meter row length }\end{array}$} \\
\cline { 3 - 4 } & & $2014-15$ & $2015-16$ \\
\hline 3 & January III & 0.3 & 0.0 \\
4 & January IV & 0.6 & 0.9 \\
5 & January V & 1.3 & 1.8 \\
6 & February I & 1.9 & 2.5 \\
7 & February II & 2.7 & 4.1 \\
8 & February III & 3.4 & 6.0 \\
9 & February IV & 5.8 & 4.9 \\
10 & March I & 4.1 & 3.7 \\
11 & March II & 3.2 & 2.6 \\
12 & March III & 2.1 & 1.2 \\
13 & March IV & 0.8 & 0.6 \\
14 & April I & 0.0 & 0.0 \\
\hline
\end{tabular}

*SMW-Standard meteorological week.

Table 2: Correlation between larval population of $H$. armigera and weather parameters.

\begin{tabular}{lll}
\hline \multirow{2}{*}{ Abiotic factors } & \multicolumn{2}{c}{ Correlation coefficient $(\mathrm{r})$} \\
\cline { 2 - 3 } & $2014-15$ & $2015-16$ \\
\hline Temperature $\left({ }^{\circ} \mathrm{C}\right)$ & $0.022 \mathrm{NS}$ & $0.884^{* *}$ \\
a. Maximum & $0.163 \mathrm{NS}$ & $0.898^{* *}$ \\
b. Minimum & & \\
Relative humidity $(\%)$ & $-0.110 \mathrm{NS}$ & $-0.761^{* *}$ \\
a. Maximum & $-0.588^{*}$ & $-0.582^{*}$ \\
b. Minimum & $0.807^{* *}$ & $0.115 \mathrm{NS}$ \\
Rainfall (mm) & $0.010 \mathrm{NS}$ & $0.8688^{* *}$ \\
Sunshine $(\mathrm{hrs})$ &
\end{tabular}

*Significant at $5 \%$ level of significance, ** Significant at $1 \%$ level of significance, NS- Non-significant. 
Relationship between Weather Parameters and Incidence of Gram Pod Borer, Helicoverpa armigera on Chickpea

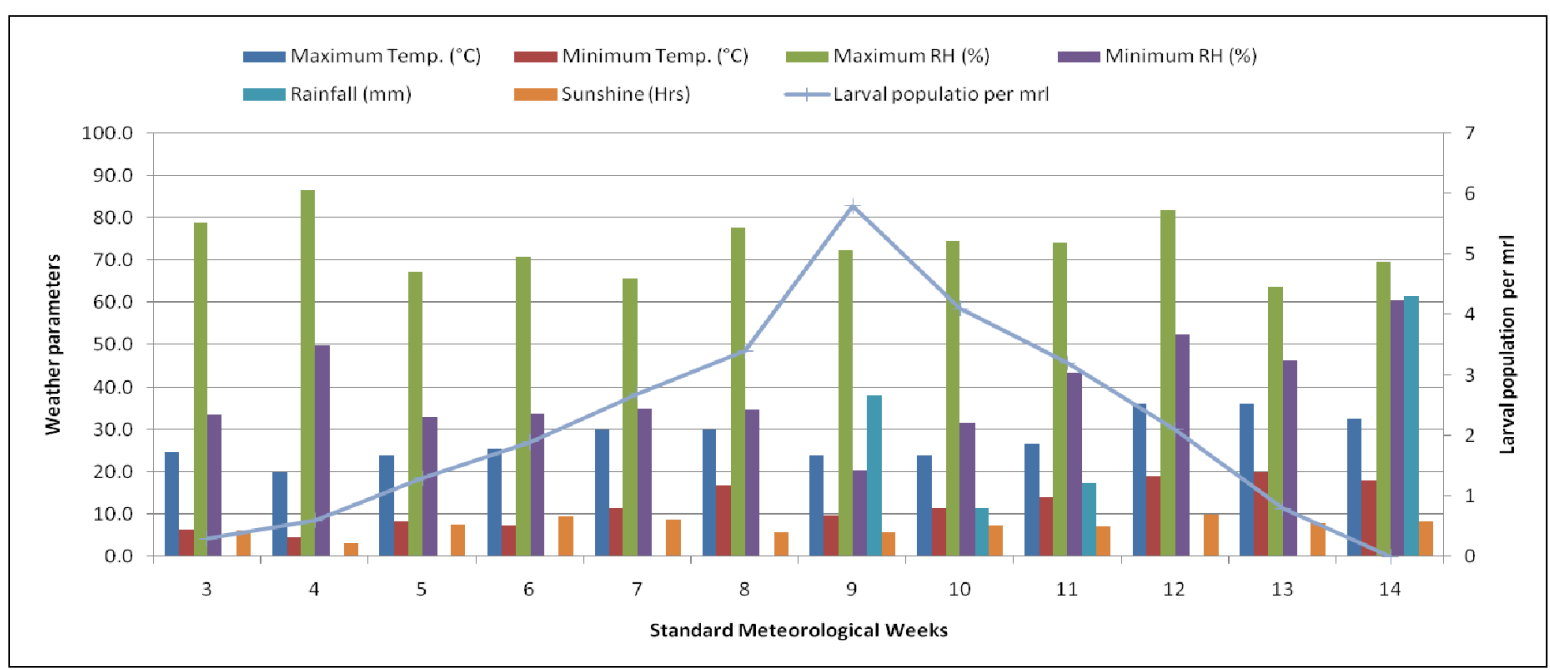

Fig 1: Seasonal incidence of Helicoverpa armigera on chickpea during rabi, 2014-15.

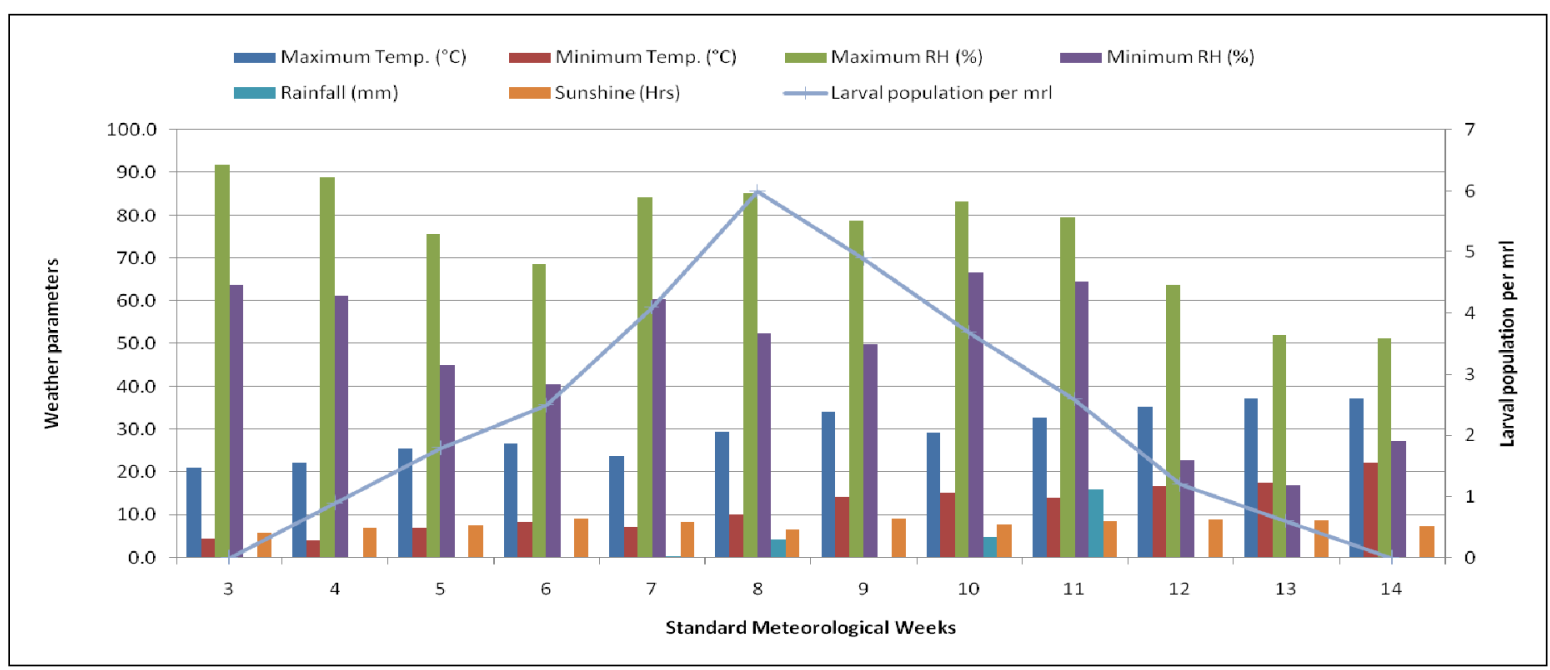

Fig 2: Seasonal incidence of Helicoverpa armigera on chickpea during rabi, 2015-16.

Table 3: Regression analysis between larval population of $H$. armigera and weather parameters.

\begin{tabular}{|c|c|c|c|}
\hline Year & Regression equation & $\mathrm{R}^{2}$ & $\mathrm{R}$ \\
\hline \multirow[t]{6}{*}{ 2014-15 } & $\mathrm{Y}=2.374-0.286 \mathrm{~T}_{\max }+0.390 \mathrm{~T}_{\min }+0.094 \mathrm{RH}_{\max }-0.152 \mathrm{RH}_{\min }+0.015 \mathrm{RF}+0.260 \mathrm{SSH}$ & 0.813 & 0.902 \\
\hline & $\mathrm{Y}=3.630-0.176 \mathrm{~T}_{\max }+0.328 \mathrm{~T}_{\min }+0.072 \mathrm{RH}_{\max }-0.154 \mathrm{RH}_{\min }+0.016 \mathrm{RF}$ & 0.777 & 0.882 \\
\hline & $\mathrm{Y}=5.798-0.247 \mathrm{~T}_{\max }+0.390 \mathrm{~T}_{\min }+0.056 \mathrm{RH}_{\max }-0.143 \mathrm{RH}_{\min }$ & 0.754 & 0.868 \\
\hline & $\mathrm{Y}=11.611-0.410 \mathrm{~T}_{\max }+0.355 \mathrm{~T}_{\min }-0.033 \mathrm{RH}_{\max }$ & 0.240 & 0.489 \\
\hline & $\mathrm{Y}=8.733-0.390 \mathrm{~T}_{\max }^{\max }+0.348 \mathrm{~T}_{\min }^{\min } \quad \max$ & 0.225 & 0.475 \\
\hline & $\mathrm{Y}=3.986-0.065 \mathrm{~T}_{\max }$ & 0.037 & 0.193 \\
\hline \multirow[t]{6}{*}{ 2015-16 } & $Y=-24.278+0.426 \mathrm{~T}_{\max }-0.168 \mathrm{~T}_{\min }+0.128 \mathrm{RH}_{\max }+0.043 \mathrm{RH}_{\min }-0.095 \mathrm{RF}+0.567 \mathrm{SSH}$ & 0.522 & 0.722 \\
\hline & $\mathrm{Y}=-21.609+0.662 \mathrm{~T}_{\max }-0.367 \mathrm{~T}_{\min }+0.057 \mathrm{RH}_{\max }+0.098 \mathrm{RH}_{\min }-0.140 \mathrm{RF}$ & 0.472 & 0.687 \\
\hline & $\mathrm{Y}=-18.194+0.458 \mathrm{~T}_{\max }-0.224 \mathrm{~T}_{\min }+0.113 \mathrm{RH}_{\max }+0.023 \mathrm{RH}_{\min }$ & 0.436 & 0.660 \\
\hline & $\mathrm{Y}=-18.847+0.417 \mathrm{~T}_{\max }-0.171 \mathrm{~T}_{\min }+0.144 \mathrm{RH}_{\max }$ & 0.432 & 0.657 \\
\hline & $\mathrm{Y}=-1.390+0.227 \mathrm{~T}_{\max }-0.251 \mathrm{~T}_{\min }$ & 0.055 & 0.235 \\
\hline & $\mathrm{Y}=2.644-0.010 \mathrm{~T}_{\max }$ & 0.001 & 0.028 \\
\hline
\end{tabular}

Where, $\mathrm{Y}=$ Larval population of $\mathrm{H}$. armigera; $\mathrm{T}_{\max }=$ Maximum temperature $\left({ }^{\circ} \mathrm{C}\right) ; \mathrm{T}_{\min }=$ Minimum temperature $\left({ }^{\circ} \mathrm{C}\right) ; \mathrm{RH}_{\max }=\mathrm{Maximum}$ relative humidity (\%); $\mathrm{RH}_{\min }=$ Minimum relative humidity (\%); $\mathrm{RF}=$ Rainfall $(\mathrm{mm}) ; \mathrm{SSH}=$ Sunshine hours (Hrs). 
of Pandey et al. (2012) and Sharma et al. (2012) they recorded negative non-significant correlation between larval population and relative humidity. Umbarkar et al. (2010), Wakil et al. (2010) and Mahawar et al. (2015) computed negative significant positive correlation with larval population and relative humidity; these findings are also supports present findings.

Rainfall showed significant and non-significant positive correlation ( $r=0.807$ and 0.115 ) with larva populationduring first and second year, respectively. The present results corroborates with the findings of Gupta and Chandel (2008), Kulhari and Singh (2008) and Kumar et al. (2015), who also found positive non-significant correlation between larval population and rainfall.Sunshine hours showed nonsignificant and significant positive ( $r=0.010$ and 0.868$)$ correlation during first and second year, respectively. Mahawar et al. (2015) recorded positive non-significant correlation with sunshine hours and larval population which supports the present findings.

\section{Regression analysis between larval population of $\boldsymbol{H}$. armigera and weather parameters}

The regression equation was computed by taking of larval population of pod borer as dependent variable and other weather parameters as independent variable. It was evident from the study that none of the weather parameters were alone responsible for larval population of pod borer on chickpea (Table 3). All weather parameters collectively accounted for 81.30 and 52.20 per cent variability in larval population of pod borer during 2014-15 and 2015-16, respectively.

\section{ACKNOWLEDGEMENT}

Authors are thankful to Department of Science and Technology, New Delhi for providing financial support. The authors are also thankful to the Dean, COA and Head, Department of Entomology, COA, Bikaner for providing necessary research facilities for conducting the experiment.

\section{REFERENCES}

Ameta, O.P. and Thakar, A.V. (1988). Assessment of losses due to insect pests of gram. Indian Journal of Applied Entomology. 2: 21-26.

Dhaka, S.S, Singh, G., Yadav, A., Mittal, V., Singh, D.V. and Singh, B. (2011). Seasonal incidence of the pod borers, Etiella zinckenella (Treitschke) and Helicoverpa armigera (Hubner) on vegetable pea in Meerut. Annals of Horticulture. 4(1): 89-94.

Dhingra, S., Kodandaram, M.H., Hegde, R.S. and Srivastava, C. (2003). Evaluation of different insecticide mixture against third instar larvae of Helicoverpa armigera (Hübner). Annals of Plant Protection Sciences. 11(2): 274-276.

Gowda, S. (1996). Comparative assessment of pyrethroid resistance in certain population of Heliothis armigera. Entomon. 16: 233-235.
Gupta, J.K. and Chandel, S.F. (2008). Seasonal incidence of gram pod borer, Helicoverpa armigera (Hubner) on chickpea. Indian Journal of Applied Entomology. 22 (2): 120-122.

Krishna, K., Kanaujia, K.R. and Kanaujia, S. (2007). Role of plant density and abiotic factors on population dynamics of Helicoverpa armigera (Hubner) in chickpea. Annals of Plant Protection Sciences. 15(2): 303-306.

Kulhari, G.L. and Singh, V. (2008). Seasonal incidence of Helicoverpa armigera (Hubner) on chickpea [Cicer arietinum (L.)]. Indian Journal of Applied Entomology. 22(2): 117-119.

Kumar, S., Singh, G., Singh, D.V., Rahul, S.N. and Kumar, S. (2015). Seasonal incidence of larval population of gram pod borer (Helicoverpa armigera Hubner) on chick pea in Meerut. Progressive Agriculture. 15(2): 259-262.

Lal, O.P. (1996). An outbreak of pod borer, H. armigera on chickpea in Eastern Uttar Pradesh. Journal of Entomological Research. 20(2): 179-181.

Mahawar, M.K., Chanu, N.Y., Nagar, R., Swaminathan, R. and Jain, H.K. (2015). Pod borer incidence and loss estimation in chickpea. Indian Journal of Applied Entomology. 29(1): 36-39.

Pandey, B.M., Tripathi, M.K. and Vijay, L. (2012). Seasonal incidence of gram pod borer Helicoverpa armigera (Hub.) on chickpea in Varanasi area. Journal of Experimental Zoology India. 15(2): 667-669.

Reddy, V., Anandhi, P., Elamathi, S. and Varma, S. (2009). Seasonal occurrence of pulse pod borer Helicoverpa armigera (Hubner) on chick pea at Eastern U.P. region. Agricultural Science Digest. 29(2): 60-62.

Reed, W. and Pawar, C.S. (1982). Heliothis: A Global Problem. In Proceedings of International Workshop on Heliothis Management. ICRISAT, Patancheru. 9-41.

Sharma, P.K., Kumar, U., Vyas, S., Sharma, S. and Shrivastava, S. (2012). Monitoring of Helicoverpa armigera (Hubner) (lepidoptera: noctuidae) through pheromone traps in chickpea (Cicer arietinum) crop and influence of some abiotic factors on insect population. IOSR Journal of Environmental Science, Toxicology and Food Technology. 1(5): 44-46.

Shinde, Y.A., Patel, B.R. and Mulekar, V.G. (2013). Seasonal incidence of gram caterpillar, Helicoverpa armigera (Hub.) in chickpea. Current Biotica. 7(1 and 2): 79-82.

Umbarkar, P.S., Parsana, G.J. and Jethva, D.M. (2010). Seasonal incidence of gram pod borer, Helicoverpa armigera (Hubner) on greengram. Legume Research. 33(2): 148-149.

Wakil, W., Ghazanfar, M.U., Kwon, Y.J., Qayyum, M.A. and Nasir, F. (2010). Distribution of Helicoverpa armigera Hubner (Lepidoptera: Noctuidae) in tomato fields and its relationship to weather factors. Entomological Research. 40(6): 290-297.

Yadav, P.C., Ameta, O.P. and Yadav, S.K. (2016). Seasonal incidence of gram pod borer, Helicoverpa armigera (Hubner) in chickpea. Journal of Experimental Zoology India. 19(1): 587-589. 